PLEASE DO NOT QUOTE FOM THIS VERSION. ORIGINAL WAS PUBLISHED AS: 'Beyond Stimulus versus Austerity : Pluralist capacity building in macroeconomics', European Journal of Economics and Economic Policies: Intervention 14 (2) 2017, pp. 267-281. URL : https://www.elgaronline.com/view/journals/ejeep/142/ejeep.2017.02.08.xml?rskey=g5Ha6b\&result $=1$

\title{
Beyond stimulus versus austerity: pluralist capacity building in macroeconomics
}

Irene van Staveren

Erasmus University Rotterdam, The Netherlands

In this article a pluralist teaching method in macroeconomics is explained with examples. It demonstrates why pluralist macro teaching is important and that it is feasible even at the introductory level. It shows how it can be carried out using five key economic theories: social economics, institutional economics, feminist economics, post-Keynesian economics and neoclassical economics. It briefly summarizes how this can be done on topics such as macroeconomic flow, economic growth, trade, poverty and well-being, and money.

Keywords: pluralism, textbooks, teaching

JEL codes: $A 22, B 50$

\section{INTRODUCTION}

Why is teaching pluralist macroeconomics important? The answer has five parts.

First, as the popular and rather mainstream British periodical The Economist claimed in July 2009 on its cover: 'Modern economic theory - where it went wrong and how the crisis is changing it'. The opening part of the statement, about economic theory getting it wrong, reflected a widely shared view among politicians, financial supervisory bodies and the general public. Much less so among economists, however.Second, the crisis provided the fatal evidence that the dominant theory in finance, the Efficient Market Hypothesis, was wrong. While the theory predicts that crisis from within the financial system cannot happen because of adequate pricing of assets with some random error, behavioural economists had warned of a burst of the various bubbles in asset markets, ranging from derivatives to the housing markets. So, finance theory required change, which even the former Chair of the Federal 
Reserve (Fed), Alan Greenspan, acknowledged later. Third, economics students who were not just interested in any well-paying job but in a meaningful job, increasingly opted for fields such as business administration, management or even political economy. Moreover, recruiters at banks suddenly found it difficult to find trainees. Fourth, in macroeconomic policy during the Great Recession that followed the crisis, the leading approach suddenly was that 'we are all Keynesians now'. Increased government expenditures for infrastructure, nationalization of banks and other key businesses such as in pension investment, subsidies for near-bankrupt companies, for example in the automobile industry, and quantitative easing by the Fed and the European Central Bank (ECB). The fifth and final part of the answer is an increased interest in the problem of inequality, thanks to work by economists such as Thomas Piketty (2014) and Sir Anthony Atkinson (2015). Interestingly, inequality was not only picked up by the usual suspects such as the United Nations (UN), but even embraced in studies and reports by the International Monetary Fund (Dabla-Norris et al. 2015) and the Organisation for Economic Co-operation and Development (OECD 2015).

These five answers make pluralist macroeconomics teaching not only more relevant but also urgent, because, since the 1980s, generations of students have been offered a very narrow menu of macroeconomic analyses, models and policy options. But the second part of the statement by The Economist, as quoted above - the hope that the crisis would change economics as we knew it - appeared to be too optimistic. Economics programmes at the undergraduate and the postgraduate level remained largely the same. The same textbooks continued to be widely used. And, after a while, most students of economics did not even care, because they chose to study economics for the good job prospects, not for understanding the real-world economy. And when a few young and entrepreneurial economic policy-makers were open to alternatives, 
they often did not know where to find them. The evening debates that we organized in the Netherlands as the Sustainable Finance Lab drew hundreds of young financial professionals, eager to learn new/old insights, beyond the mainstream that they were taught. Many economically trained professionals and policy-makers appeared completely unaware of the rich history of economic thought with a plurality of insights in macroeconomics. So, if no one else did it, I decided that I should write a pluralist introductory economics textbook (van Staveren 2015). It should cover both microeconomics and macroeconomics from a variety of theoretical perspectives. (For two shorter pieces on teaching pluralist macroeconomics, see van Staveren 2009 and 2014.) In this article, I will give you a brief insight into how I have done this for the macroeconomic part of the textbook (which from January 2017 is also available as an online course through the platform Coursera, 'Introduction to economics from a pluralist perspective'). Section 2 deals with the methods in pluralist economics teaching. Sections 3 to 5 focus on teaching social macroeconomics, institutional macroeconomics and feminist macroeconomics, respectively. Section 6 very briefly concludes.

\section{METHODS IN PLURALIST ECONOMICS TEACHING}

\subsection{Approach}

I have opted for presenting four key economic theories across the spectrum.

Obviously my choices of what to include in each chapter and which concepts and insights to attribute to each theory are debatable. This is as far as I know the first textbook of its kind and surely not perfect. I have decided to present the four theories in every chapter from broad to narrow: 
- $\quad$ social economics;

- institutional economics;

- $\quad$ post-Keynesian economics; and

- neoclassical economics.

I have also decided to present the theories more or less as they are in their most simple form, without much comment on differences and disagreements. This helped me to prevent two pedagogical traps, often found in heterodox books that seek to convince readers to abandon neoclassical economics:

- an elaborate critique of neoclassical economics, which would crowd out space for the other theories; and

- neoclassical economics bashing, which is to me a waste of time, because preliminary students of economics don't know that theory anyway and one unwittingly reinforces the dominance of that theory by giving it so much attention.

Every chapter (an introduction, eight micro chapters and six macro chapters) is contextualized with a particular country experience. So, along the way, students also learn about a wide diversity of real-world economic systems, activities, strategies and policies.

Let me now briefly show how this works out for two macroeconomic topics: the macroeconomic flow and the drivers of growth.

\subsection{The macroeconomic flow in four theories}

The macroeconomic flow in social economics demonstrates that the economy is considered to be embedded in society, which in turn is embedded in nature. Moreover, 
it visualizes the role of communities in the economy, as the third domain of economic activity next to markets and the state. Finally, it shows that the interactions with communities centres around households and consists of flows of unpaid service delivery and unpaid work, along with these social and ecological services to others in the community, wider society and nature. See Figure 1 for a visualization of the social economic macroeconomic flow.

Figure 1. The macroeconomic flow in social economics

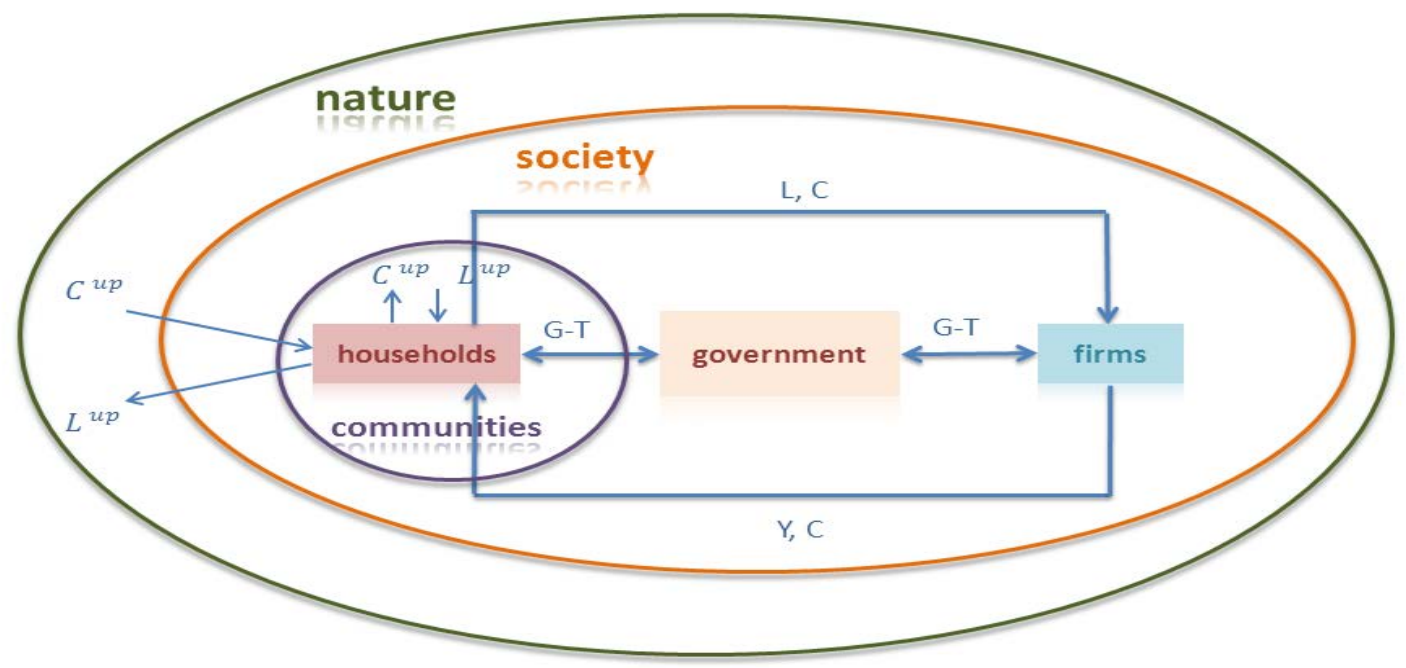

Source: Van Staveren (2015: 259).

In institutional economics, the macroeconomic flow emphasizes the role of formal institutions and informal institutions, shaping the interactions between the key actors in the economy (see Figure 2). I also added the rest of the world (ROW) in this flow diagram, but that could have been introduced in the first one as well, of course. However, in order to prevent too much information at once, it is introduced here, in the second flow diagram. Formal institutions are pictured as arrows alongside the arrows for flows of money, production factors and goods. Informal institutions are pictured as an additional domain of economic forces, which some refer to as culture, others as social norms, and yet others as the moral economy. Precisely because of this characterization as distinct from the economy but nevertheless influencing and being 
influenced by the economy I gave it its own domain. This contrasts with formal institutions, which are rules, procedures and laws that emerge in one domain and affect another, so moving with arrows between domains rather than forming a domain of their own.

Figure 2. The macroeconomic flow in institutional economics

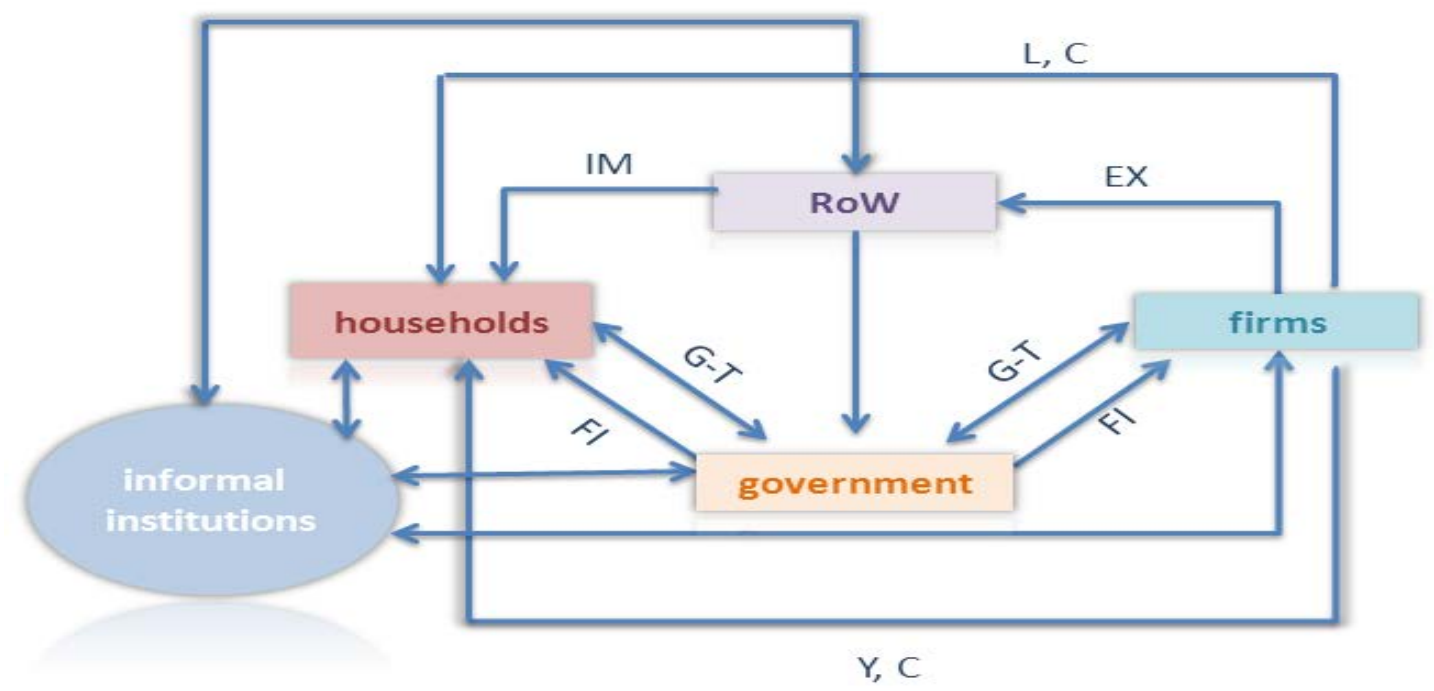

Source: Van Staveren (2015: 262).

The post-Keynesian macroeconomic flow has two key characteristics (see Figure 3). First, it makes the monetary economy visible, or more precisely the FIRE (Finance, Investment and Real Estate) sector. This helps students to understand the nonneutrality of money. Second, it demonstrates the idea of feedback effects at the macro level, which helps students to understand the fallacy of composition. This is done with two additional flows, of injections and leakages.

Figure 3. The macroeconomic flow in Post Keynesian economics 


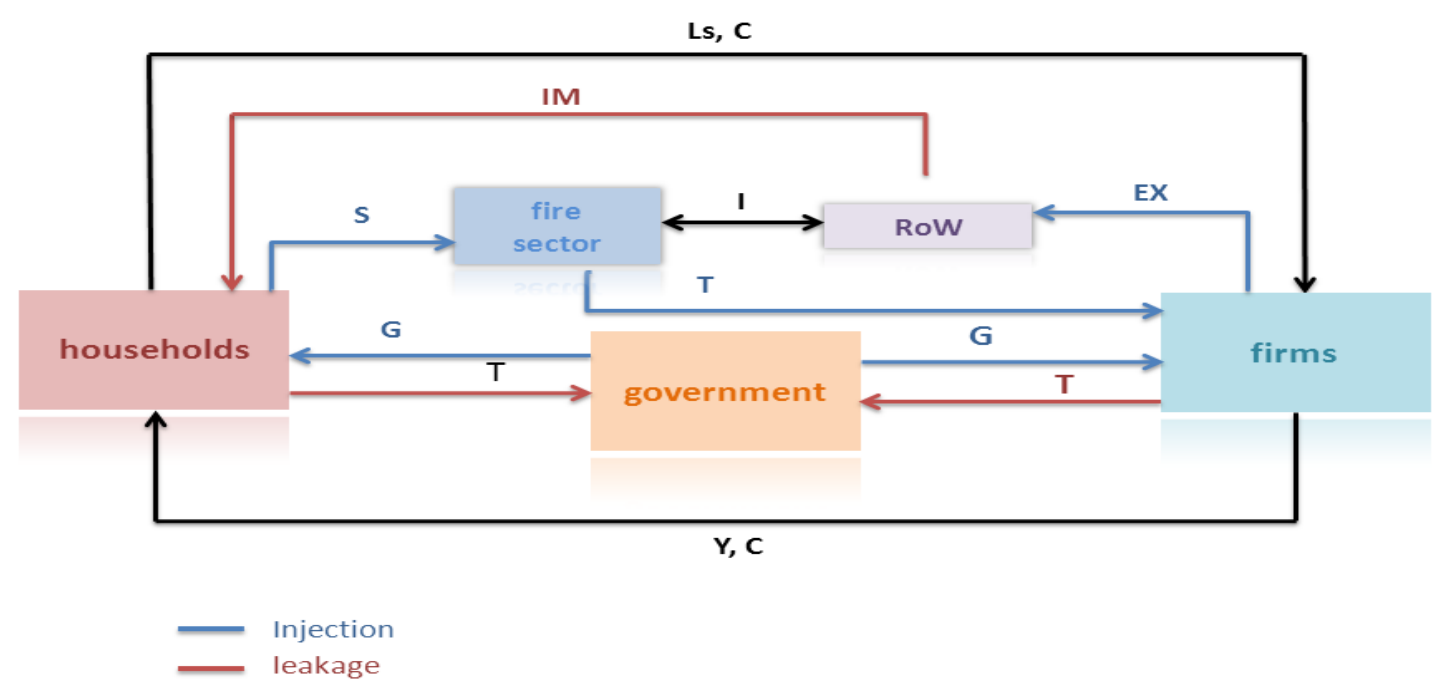

Source: Van Staveren (2015: 270).

Finally, the neoclassical macroeconomic flow (see Figure 4). What becomes immediately clear from the visualization is that it is a closed systems flow. The economy is not embedded in society, does not acknowledge the economic role of communities and culture, and nature is simply a resource, without feedback effects from economic activity on its size, quality, diversity and sustainability, even as a provider of resources. What is made explicit here is the role of politics in influencing the government. This enables students to understand why neoclassical economists are often so critical about the role of government: it is not necessarily benefiting the economy, or markets to be more specific, but has its own role which may, through government policies, negatively influence the economic choices and constraints of firms, households and the ROW through trade regulation. 
Figure 4. The macroeconomic flow in neoclassical economics

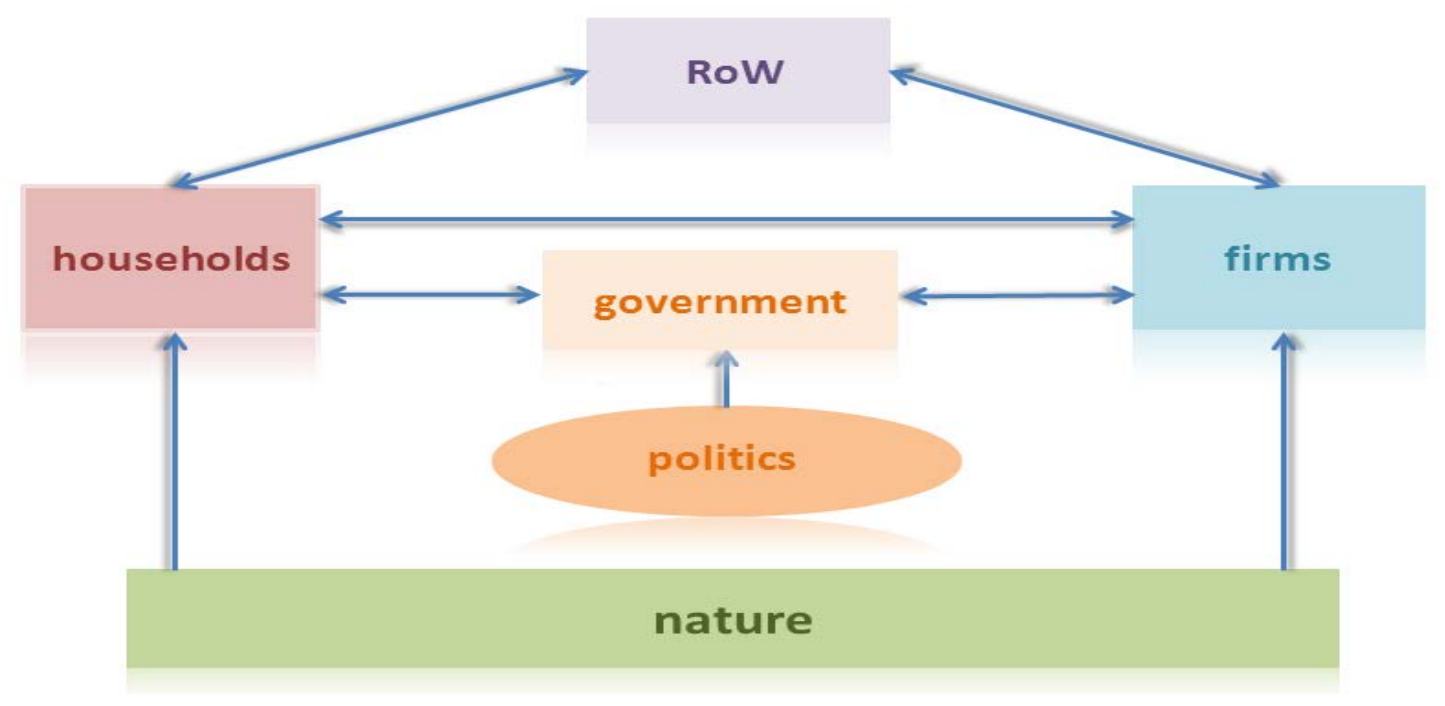

Source: Van Staveren (2015: 275).

\subsection{The drivers of growth in four theories}

Each of the four theories has its own growth theory. Some more elaborate than others, of course. But they clearly have distinct views on the drivers of economic growth, next to the two key resources, capital and labour, which feature in all four theories. In order to help students avoid getting confused between what is similar and what is different, I have introduced the distinguishing feature as the mysterious Xfactor. In social economics, this refers to the social, the meso level of the economy where relationships matter. This includes trust, cooperation, collective action and shared norms. Together, a positive X-factor results in social cohesion, which several empirical studies have indicated benefit economic growth, using a wide variety of measures (for a recent contribution to this debate, see van Staveren/Pervaiz 2017). A negative X-factor stands for social exclusion and discrimination, negatively affecting growth. In institutional economics, the $\mathrm{X}$-factor is represented by developmental institutions, as listed and argued by, for example, development economist Ha-Joon 
Chang (2003 and 2007a). Such institutions, including development banks, infant industry protection, and free primary and secondary education, have been shown for decades to stimulate economic growth, first in the now-rich countries of the OECD, and later for the Asian tiger economies.

In post-Keynesian economics, the $\mathrm{X}$-factor is not an additional variable reflecting a resource or lubricant for growth, but, rather, the feature of endogeneity at the macroeconomic level. In particular the simultaneous determination of $r$, the profit rate, and $g$, the growth rate. Hence, the X-factor in post-Keynesian economics points at the internal dynamics of growth, with its feedback effects. Finally, in neoclassical economics, the New Growth theory points at the qualitative dimensions of $L$ and $K$, through human resources (HR) and technology (T). So, there are actually two Xfactors at work in the new growth theory, the quality of the labour force and the level of technology in the capital stock, and it is precisely through these qualitative features measured as HR and T that growth may show increasing returns.

Now that I hope I have clarified my approach of presenting four theories, from broad to narrow on every topic, let me go deeper into the macroeconomic chapters of the book for each theory. Due to lack of space, I will present two heterodox theories plus a theory that I have not treated separately in the book but in connection with one or more of the other theories: feminist economics.

\section{SOCIAL MACROECONOMICS TEACHING}

\subsection{Embedded economy}

The most basic characteristic of social economics, as was also shown with the macroeconomic flow diagram in the previous section, is the embeddedness of the 
economy in society and nature. This may be referred to as a social contract between economic actors and society. For firms, the social contract provides legitimacy, or a licence to operate. In turn, this may reduce transaction costs in its interactions with labour unions, investors, the tax office, supervisory bodies and the environmental movement, for example. For the government, the social contract has political meaning, and shapes the social relations between economic actors. For example, through a legal minimum wage, a level playing field in regulation for firms, and social security for all.

But in social economics there is another important domain alongside firms operating in the market and government representing the economic roles of the state: the community economy. Here, also, a social contract facilitates interactions and reduces costs, for example by recognizing the importance of unpaid work and the services that economic agents provide for free to society and nature. Only with recognition of the economic value of these activities for the economy, and with support for this social value creation in a social contract, will the community economy be able to sustain itself and to continue creating new generations of workers in the labour force, for example. Moreover, a well-functioning community economy will enhance social cohesion, which, as I have discussed above, is an economic growth driver in social economics.

\subsection{Money as a social relation}

In social economics, money has not only the well-known three functions of unit of account, means of exchange and store of value, but it is also the only means of accumulation in a capitalist economy. This can be illustrated with the sequence of $M-$ $C-M^{\prime}-C^{\prime}-M^{\prime \prime}$. Moreover, in social economics, money is first and foremost understood as a social relation of trust and debt. This is because it enters the economy through 
bank credit as debt. These characteristics of money also enable students to have a social-economic understanding of the 2007/2008 crisis from a money perspective.

\subsection{Dependency theory}

The next macroeconomic insight of social economics that I present is in the chapter on trade. I introduce the dependency theory, explaining why trade between unequal partners (in terms of their level of economic development, for example measured by GDP per capita) does not necessarily benefit both trading partners. This is particularly the case in the long run where those countries located in the periphery (mostly lowincome developing countries) tend to find themselves locked in within trade relationships which generate very low value added and largely benefit the countries in the centre. Moreover, they tend to experience deteriorating terms of trade with the countries in the centre, as explained by the Prebisch-Singer hypothesis. That is precisely why in social economics trade analysis has shifted to global value chain analysis, which allows for an explanation of where the power is located that reduces the gains from trade for many developing countries.

\subsection{Value chain analysis}

This type of analysis helps us to see, for particular value chains, how specialization on unskilled labour in the production of intermediate goods has low value added, and how the lead firms, often operating as oligopolists, tend to reap surplus profits. Moreover, it helps to explain why the situation does not improve over time with more and more manufacturing being done in the global south: it is due to the competition between low-wage countries for entry into global value chains, implying a race to the bottom in terms of value added, wages and labour conditions. 


\subsection{Multi-dimensional poverty}

Finally, in the chapter on poverty and well-being, I show the important contributions of social economics to analysing these phenomena through the capability approach, with its Human Development Index and more elaborate measures of poverty and wellbeing (UNDP reports for various years). I illustrate this with comparisons of country rankings along various poverty indices such as the multi-dimensional poverty index. In line with the social-economic growth theory's X-factor defined as social cohesion, poverty is explained in this theory as social exclusion, a negative $\mathrm{X}$-factor. This arises from the interplay between market forces (such as in global value chains), social protection deficiencies (often as a consequence of neoliberal policies), and discriminatory social norms, legitimizing child labour, wage discrimination of women, and exploitation of immigrant workers, for example.

\section{INSTITUTIONAL MACROECONOMICS TEACHING}

\subsection{Institutions of growth}

The part on institutional economics in the chapter on economic growth goes into the ten key institutions of growth, as listed by Ha-Joon Chang (2007a). In class, I connect each institution with a real-world example, depending on the country context of my students.

\subsubsection{State-owned firms beyond public-good production}

An example could be KLM-AirFrance, which still has a majority share by the state. This indicates that state-owned forms outside the area of clear public goods such as drinking water and primary education are not only something we find in (former) socialist countries such as Russia and China, but also in Western, highly developed countries. 


\subsubsection{State-owned banks and development banks}

Here I give the example of Brazil's successful national development bank, BNDES. It is profitable and at the same time undertakes investments in innovations that privatesector parties often do not take because of the long time period before reaping returns on investment and uncertainties in certain markets.

\subsubsection{Land reform and income redistribution}

Here, land reform in South Korea in the 1950s is a good example. It opened up access to land for large numbers of landless farmers, which helped to increase agricultural output and productivity. This, in turn, was a precondition for successful industrialization to take off.

\subsubsection{Widely accessible and good quality free education at all levels}

This is widely agreed to be an important precondition for increased labour productivity and the shift of labour to new, upcoming sectors in relation to modernization and trade specialization. Precisely for that reason, this institution was made part of the 2000-2015 Millennium Development Goals (MDGs) and, in a more ambitious form, of the 2015-2030 Sustainable Development Goals (SDGs).

\subsubsection{Good quality health care and sanitation}

Again, this is an important precondition for increased labour productivity. But it also helps to prevent costs of extreme poverty and illness. And, again, we see this reflected in the MDGs and the SDGs.

\subsubsection{Industrial policy including subsidies for selected growth sectors}

The empirical evidence provided by Ha-Joon Chang is of course the trade protection and subsidies in Britain in the eighteenth and nineteenth centuries and in Europe in 
the first half of the twentieth century, until industries were competitive enough to reduce tariffs and eliminate subsidies, and to kick away the ladder for developing countries who were not allowed to follow the same successful strategy in the name of globalization. A good example today is China, which gradually turns its most successful State Owned Enterprises into competitive private-sector firms.

\subsubsection{First labour-intensive, then capital/technology catch-up}

Here, the obvious example of the past half century is the Asian tiger economies, and the so-called baby tigers (Thailand and Indonesia, for example).

\subsubsection{Capital-account controls and selective FDI}

The countries that escaped the collapse in the wake of the 1997 Asian Financial Crisis

- China and India - both had capital controls. And they still have them, also insulating them from contamination from the negative effects of the 2007-2008 financial crisis. Careful capital-account policies help developing countries to protect themselves against foreign financial instability, but also put a brake on domestic-level speculation and the asset bubbles that often follow from this.

\subsubsection{Infant-industry protection}

This development institution overlaps with number 6 named above, but is more specific for trade protection with high import tariffs. Data of tariffs clearly demonstrate that Europe had high tariff walls from the late nineteenth century up until the 1970s. See Table 1, with data taken from Chang (2007b). 
Table 1 Historical trade tariffs

\begin{tabular}{|l|l|l|}
\hline Country & 1875 & 1931 \\
\hline Austria & $15-20$ & 24 \\
\hline Belgium & $9-10$ & 14 \\
\hline France & $12-15$ & 30 \\
\hline Germany & $4-6$ & 21 \\
\hline Italy & $8-10$ & 46 \\
\hline Russia & $15-20$ & \\
\hline Spain & $15-20$ & 63 \\
\hline Sweden & $3-5$ & 21 \\
\hline Switzerland & $4-6$ & 19 \\
\hline US & $40-50$ & 48 \\
\hline
\end{tabular}

Source: Ha-Joon Chang (2007b), reprinted in van Staveren (2015: 26).

\subsubsection{Rule of law, even with high corruption}

This is a very interesting development institution. On the one hand, economists focusing on good governance argue that it is the key institution for development to sustain itself over time, even when a country has abundant resources. On the other hand, some countries show that they do well even when some elements of what is considered to be a good rule of law are not in place, such as corruption. This is, for example, the case in China.

\subsection{Efficiency of redistribution of resources}


Figure 5. The efficiency of land redistribution
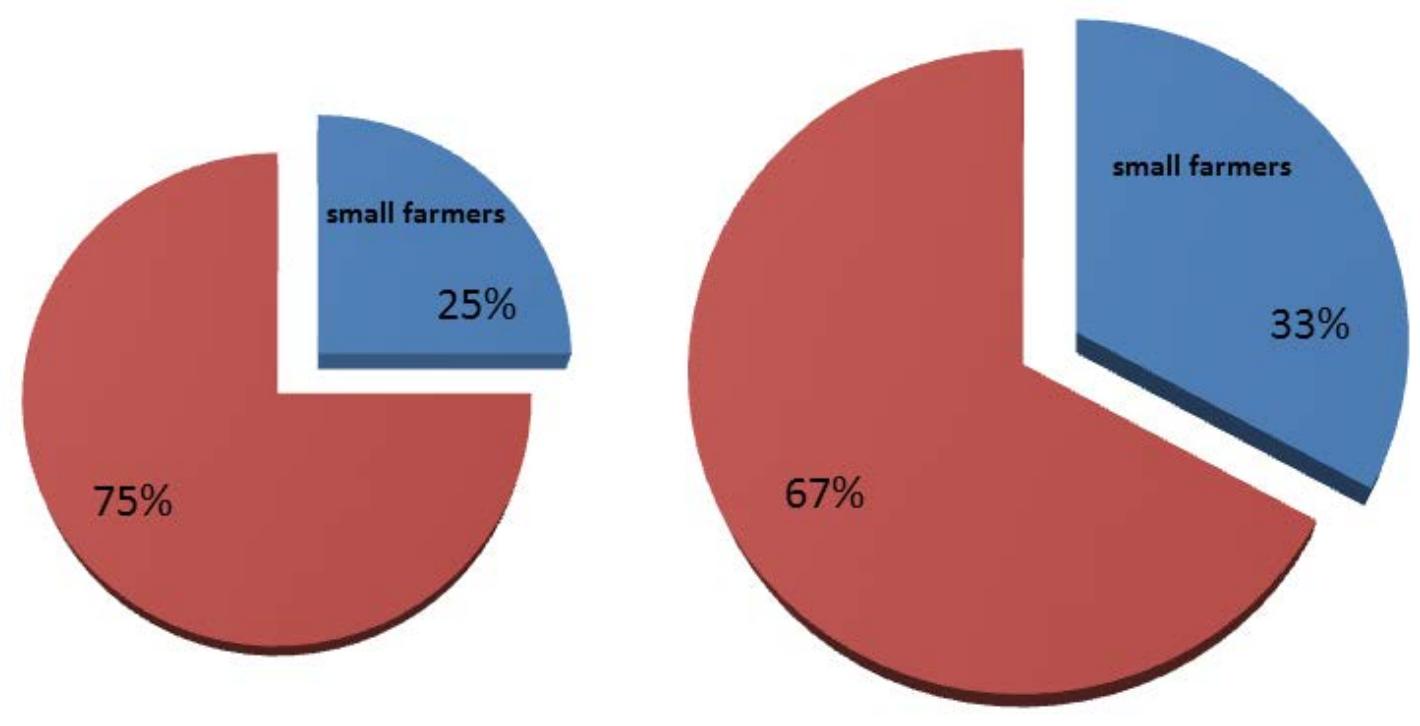

Source: Van Staveren (2015: 313).

Among the ten key development institutions, number 3 referred to land reform.

There, it was linked to allocative efficiency, through providing access for landless farmers to agricultural land. But there is a wider efficiency gain, namely a dynamic efficiency gain. Figure 5 illustrates this. This is related to the law of diminishing marginal returns in combination with the fact that most small farmers only have labour to use on their land, and will do that to the maximum, leading to a high intensity of land use. Big land-owners, however, use more capital goods and therefore do not work all the land intensively, due to stony ground, steep hills, flood areas, etc. Moreover, some big land-owners do not use the land to grow crops at all, but keep it idle to show off their status, which the founder of institutional economics, Thorstein Veblen (1899), had already noticed in late nineteenth-century America.

\subsection{Inequality}

A final theme from the institutional perspective is inequality. I distinguish between vertical inequality (largely income inequality) and horizontal inequality (for example, between sex, ethnic origin or rural-urban regions). 
Figure 6 shows a world map indicating the global rise in income inequality since the 1980s.

Figure 6. Increasing income inequality since the 1980s

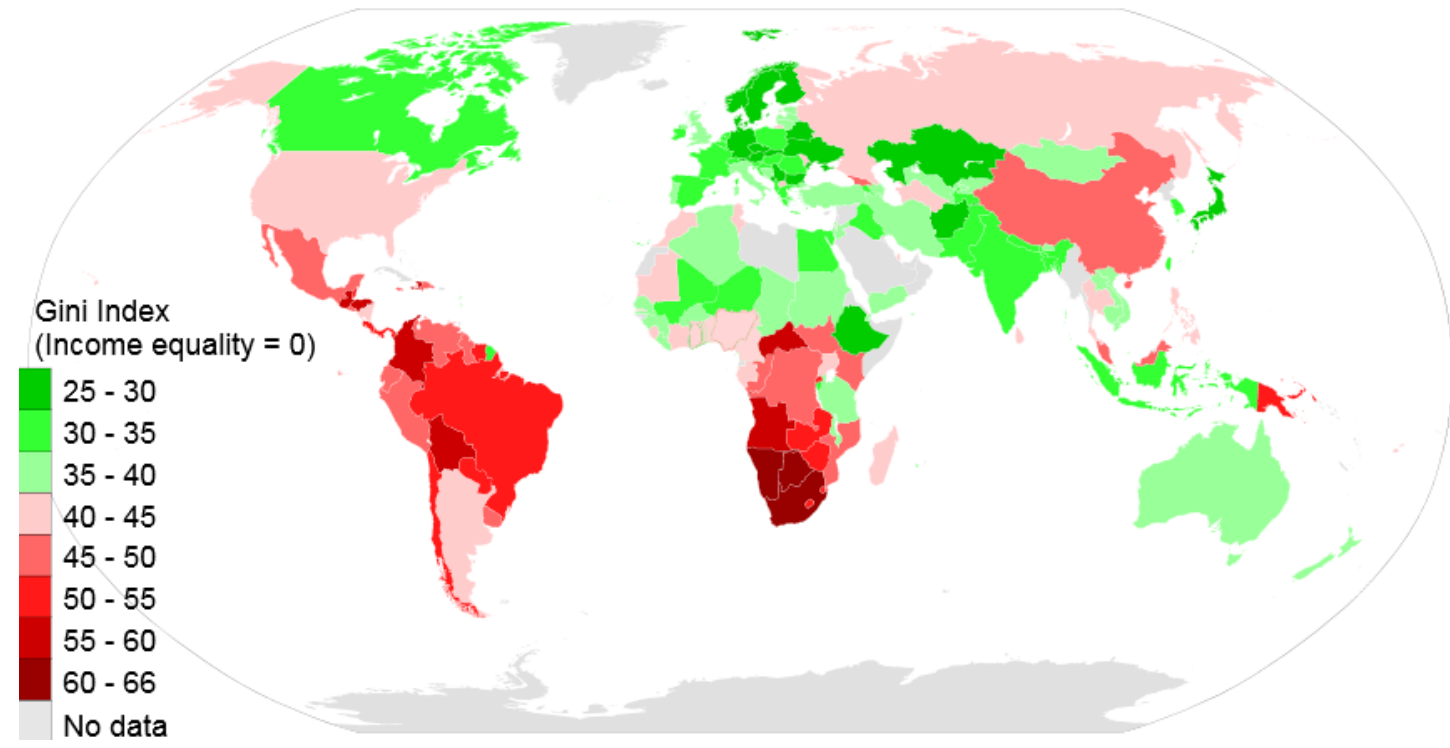

Source: M Tracy Hunter, https://commons.wikimedia.org/w/index.php?curid=33962866

This can be compared with the phenomenon of horizontal inequality. Table 2 shows, for example, the difference in the Gender Equality Index (GEI) for three countries in the Middle East, showing considerable variation in gender inequality within this region. The GEI is a broadly constructed index across various sectors and it forms part of the Indices of Social Development, a database coordinated at the International Institute of Social Studies (ISS 2017).

Table 2. Variation in gender inequality in the Middle East, 2010

\begin{tabular}{|l|l|}
\hline Country & GEI \\
\hline Oman & 0.70 \\
\hline Egypt & 0.65 \\
\hline
\end{tabular}


\begin{tabular}{|l|l}
\hline Yemen & 0.59
\end{tabular}

Source: Adapted from van Staveren (2015: 404).

Table 2 shows one of the various connections between institutional economics and feminist economics. It considers gender inequality to be an institution, and in particular a disabling institution for the economic behaviour of women. The next section will present a brief overview of three theoretical stances in feminist economics.

\section{FEMINIST MACROECONOMICS TEACHING}

Most economists who are not familiar with feminist economics assume that it only deals with microeconomics and topics such as household economics and labourmarket discrimination. However, over the past two decades various feminist economists have developed feminist concepts, analyses and theories at the macro level. These include growth theory, trade, and welfare analysis.

In general, feminist economics contributes three elements to macroeconomics:

- It brings in horizontal inequality, which is cross-cutting vertical inequality, but affecting productivity and growth at least as much.

- It provides a cross-cutting perspective on economics rather than adding just one topic or variable or method.

- It strengthens pluralism in economics by deconstructing the assumption of Rational Economic Man (sic!), by drawing attention to unpaid work and the care economy, and by adding new forms of power, often implicit and invisible, 
next to market power.

This section will now very briefly give some examples of how feminist economics has contributed to macroeconomics from a post-Keynesian, institutional and neoclassical perspective.

\subsection{Post-Keynesian feminist macroeconomics}

The cross-fertilization between post-Keynesian and feminist economics is potentially large (Danby/van Staveren 2010). Let me take just two overarching concepts in each theory: gender and money. For gender, a critical gender analysis of post-Keynesian economics shows that implicit gender dualisms, such as rational/emotional, public/private, material/immaterial are present in post-Keynesian economics just like in neoclassical economics. In general, post-Keynesian analysis favours market analysis over household analysis, money exchange over unpaid interactions, and economic man over economic woman, with the key figures of asset investors, labourers, and a seemingly gender-neutral consumer. However, male and female consumer patterns tend to differ, and so will their propensities to consume, which would affect the multiplier. Moreover, the household is exclusively regarded as the place of consumer spending and saving, but not as the location where the labour force is reproduced and where gender norms are reinforced and reproduced. As such, these feminist insights would help to deepen the understanding of involuntary unemployment beyond the lack of effective demand, by combining the issues of segmentation and involuntary unemployment with gender norms and the care economy. By looking into households, the post-Keynesian thesis of interdependence of supply and demand could be deepened: they are interrelated even at the same location, through the combination of economic roles of household 
members. Finally, the post-Keynesian analysis of non-entirely rational behaviour captured by the concept of animal spirits may be complemented by the notion of caring spirits, which helps to provide buffers against the costs arising from the decisions taken on the basis of animal spirits (see, for example through caring finance, van Staveren 2013a). We might want to analyse gender differences in liquidity preferences, for example.

Moreover, unpaid work can function as a stabilizer or, alternatively, reinforcer, of economic cycles through the substitution and complementary functions of unpaid production of consumer goods and services (Ertürk/Çaĝatay 1995).

Feminist economics can benefit from key post-Keynesian insights in relation to the analysis of money as non-neutral. The concept of uncertainty may be linked to women's life events, influencing their economic choices, such as pregnancy and child-caring responsibilities as well as the experience of gender discrimination and gender-based violence. The idea of non-equilibrium seems a good alternative to the dominant household-bargaining approach of a stable (Nash) equilibrium. And finally, the idea of endogenous change could be applied to unpaid work and caring in feminist economic analyses.

\subsection{Institutional feminist macroeconomics}

I have already given examples of this theoretical combination, when I mentioned horizontal inequality and equal access to education and health care as part of the ten key development institutions. That is why I will be brief here. I will take the example of horizontal inequality, measured as the extent of gender equality, a step further by showing how both formal and informal gendered institutions reduce gender equality. 
See Figures 7 and 8 for an illustration of these relationships for the Middle East and North Africa (MENA) region. The GEI data are, as before, from the database Indices of Social Development. The data on the gendered institutions are from the OECD database of Structural Institutions of Gender Inequality (http://www.genderindex.org/).

Figure 7. Constraints to women's access to resources \& gender equality, MENA region, 2010

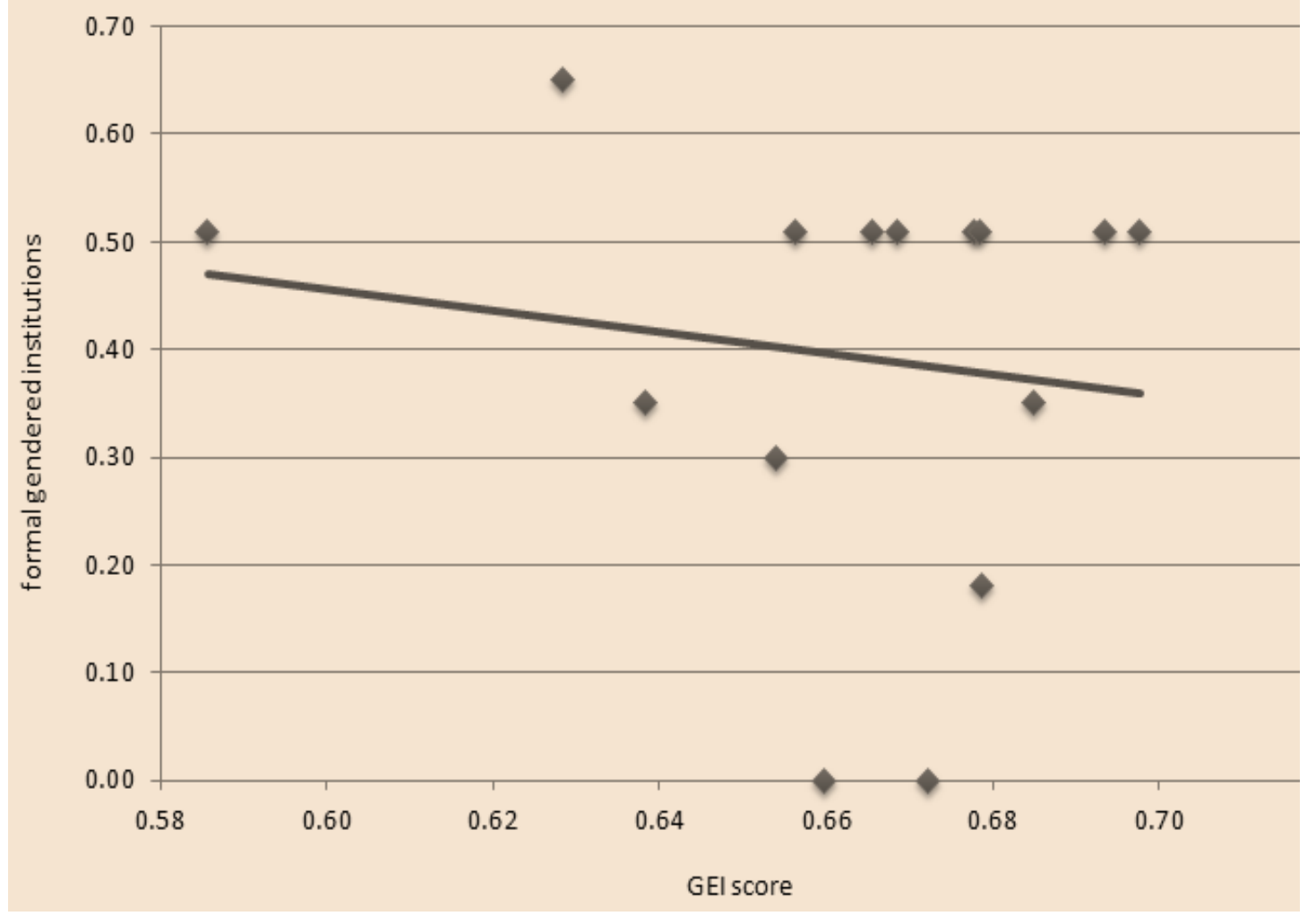

Source: Van Staveren (2015: 405). 
Figure 8. Constraints to women’s civil liberties \& gender equality, MENA region, 2010

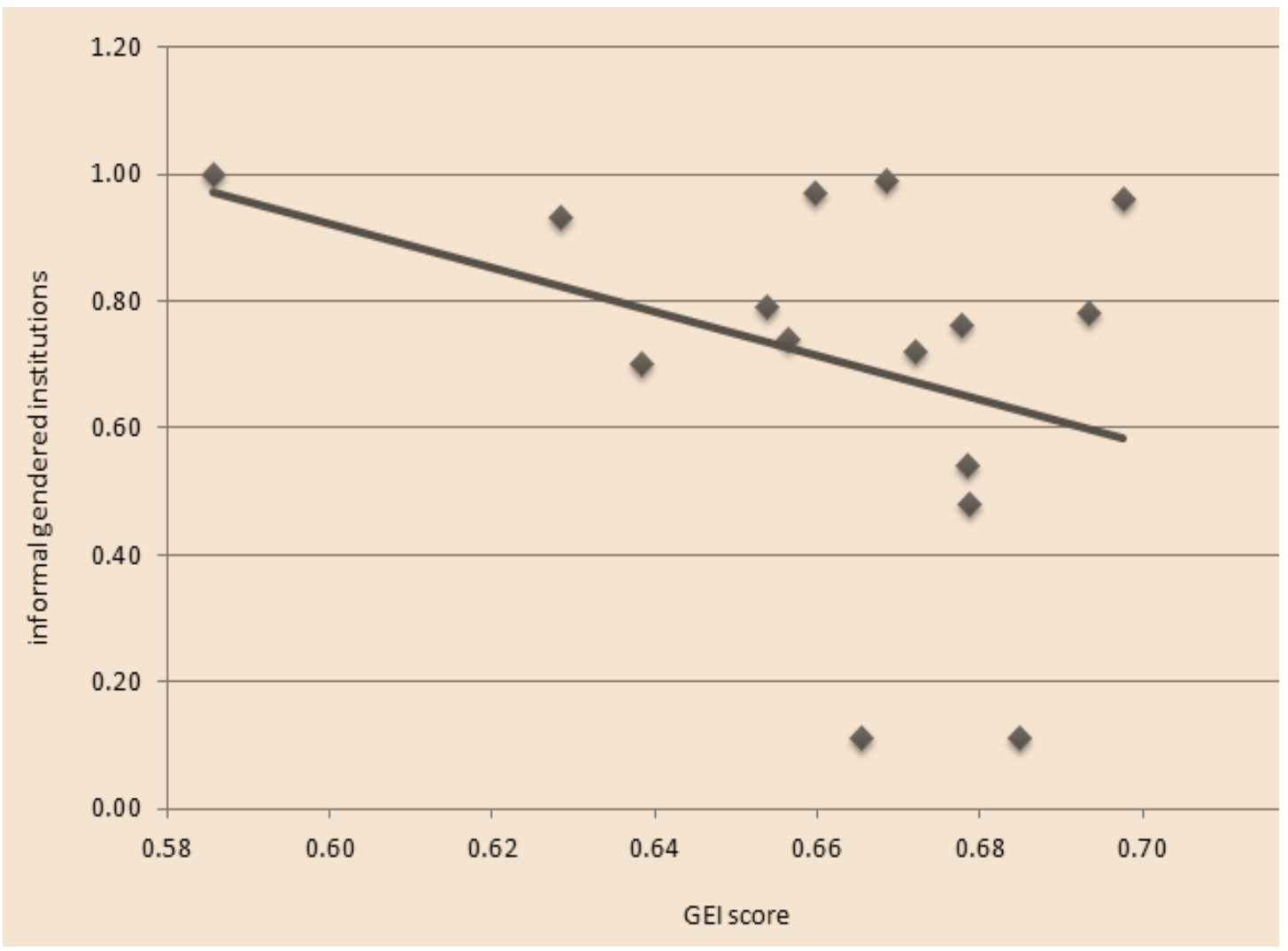

Source: Van Staveren (2015: 405).

More generally, gendered institutions can be conceptualized as asymmetric institutions (Odebode/van Staveren 2007), which can hamper women’s wellbeing outcomes (van Staveren 2013b).

\subsection{Neoclassical feminist macroeconomics}

Neoclassical welfare analysis can easily incorporate gender inequality, but the conclusion tends to be the opposite from the one derived from income inequality. In other words, vertical inequality and horizontal inequality may have very different welfare consequences, in neoclassical analysis.

In the case of gender inequality, the focus is on access to resources, such as education or credit. When women have less access to such resources as compared to men, their 
productivity will remain below their capacity and below that of men. Such underutilization of human resources leaves a gender-biased economy underperforming. This can be illustrated with the help of the possibility frontier (Figure 9). As is well known, any point at the frontier ( $A, B$ or $C$ ) reflects maximum efficiency of the use of resources $X$ and $Y$ in an economy. Hence, point $E$ is not attainable given resource constraints. But point $D$ shows inefficient use of resources. This may reflect gender discrimination in the access to schooling or credit or land in an economy. The solution to this inefficiency would be to redistribute part of these resources from men to women until their marginal productivities are equalized. This would move an economy from $D$ in the direction of the possibility frontier, for example between points $B$ and $C$ as indicated by the arrow. With a redistribution of places in school, credit or land from boys to girls and from men to women, women's productivity would, in neoclassical analysis, increase more than the loss in male productivity, because the males are already using these resources at higher levels, with lower marginal returns. So, total productivity in the economy would increase. 
Figure 9. Possibility frontier and gender inequality

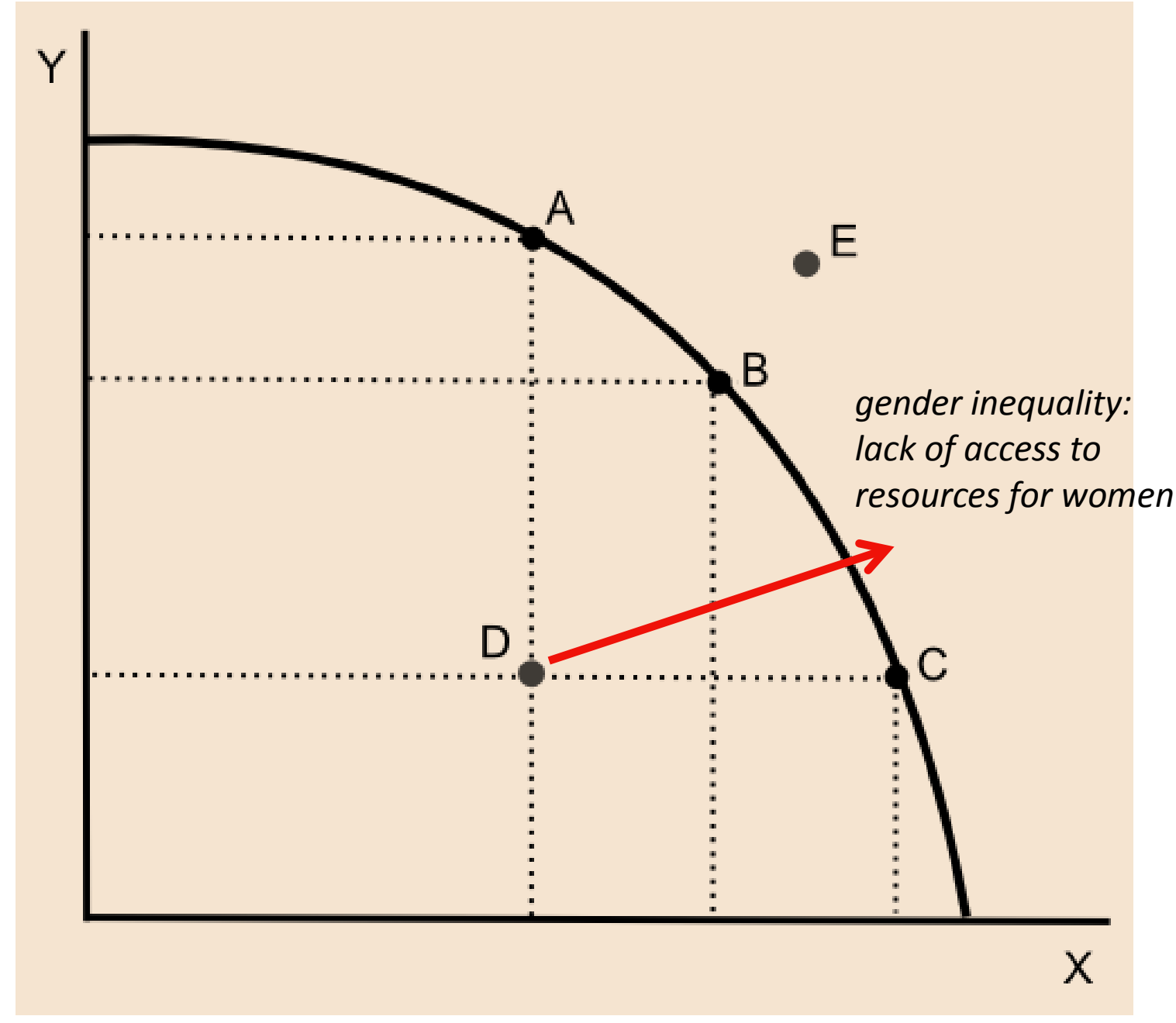

Source: Van Staveren (2015: 415).

Some authors have estimated the size of the efficiency loss due to gender inequality in access to resources and have found long-run growth losses of up to 50 per cent for example when comparing Africa with Asia (Klasen 2009).

\section{CONCLUSIONS}

I hope that these brief examples have given an idea of what pluralism brings to macroeconomics. To summarize this potential: 
Pluralism:

- is possible drawing on the rich history of economic thought;

- is necessary to make economics real-world relevant;

- is a response to the demands of the international Rethinking Economics movement;

- is macroeconomics to its full potential. 


\section{REFERENCES}

Atkinson, A. (2015): Inequality: What can be Done? Cambridge, MA:

Harvard University Press.

Chang, H.-J. (2003): Kicking Away the Ladder: Development Strategy in Historical Perspective, London: Anthem Press.

Chang, H.-J. (2007a): Bad Samaritans: Rich Nations, Poor Policies, and the Threat to the Developing World, London: Bloomsbury Press.

Chang, H.-J. (2007b): Kicking away the ladder: the 'real' history of free trade, in Shaikh, A. (ed.), Globalization and the Myths of Free Trade: History, Theory and Empirical Evidence, London: Routledge.

Dabla-Norris, E., Kochhar, K., Suphaphiphat, N., Ricka, F., Tsounta, E. (2015):

Causes and consequences of income inequality: a global perspective, IMF Staff Discussion Note, New York: International Monetary Fund.

Danby, C., van Staveren, I. (2010): Introduction to the symposium on post-Keynesian and feminist economics, in: Cambridge Journal of Economics, 34(6), 11051107.

Ertürk, K., Çaĝatay, N. (1995): Macroeconomic consequences of cyclical and secular changes in feminization: an experiment in gendered macromodelling, in: World Development, 23, 1969-1977.

ISS (2017): Indices of Social Development database, The Hague: International Institute of Social Studies, URL: www.IndSocDev.org.

Klasen, S., Lamanna, F. (2009): Gender inequality in education and employment and economic growth: new evidence for developing countries, in: Feminist Economics, 15(3), 91-132.

Odebode, S., van Staveren, I. (2007): Gender norms as asymmetric institutions: a case 
study of Yoruba women in Nigeria, in: Journal of Economic Issues, 41(4), 903-925.

OECD (2015): Why Less Inequality Benefits All, Paris: OECD.

Piketty, T. (2014): Capital in the Twenty-First Century, Cambridge, MA: Harvard University Press.

UNDP (various years): Human Development Report, New York: United Nations Development Program, URL for the reports and data: http://hdr.undp.org/en/data.

Van Staveren, I. (2009): A pluralist approach to intermediate macroeconomics, in: Reardon, J. (ed.), The Handbook of Pluralist Economics Education, London: Routledge, 93-119.

Van Staveren, I. (2013a): Caring finance practices, in: Journal of Economic Issues, 47(2), 419-425.

Van Staveren, I. (2013b): An exploratory cross-country analysis of gendered institutions, in: Journal of International Development, 25(1), 108-121.

Van Staveren, I. (2014): Gender as a macro economic variable, in: Rai, S., Waylen, G. (eds), New Frontiers in Feminist Political Economy, London: Routledge, 135-153.

Van Staveren, I. (2015): Economics after the Crisis: An Introduction to Economics from a Pluralist and Global Perspective, London: Routledge.

Van Staveren, I., Pervaiz, Z. (2017): Is it ethnic fractionalization or social exclusion, which affects social cohesion?, in: Social Indicators Research, 130(2), 711731.

Veblen, T. (1899): The Theory of the Leisure Class: An Economic Study of Institutions, London: Macmillan. 